\title{
Cikkismertetés: Hogyan növelhető bizonyított hatékonysággal az egészségműveltség?
}

Article review: How to improve health literacy on an effective way?

Ismertető: $\quad$ Mátyás Gabriella $\square$

Debreceni Egyetem, Megelőző Orvostani Intézet, Egészségfejlesztési Tanszék

Ismertetett cikk: Rowlands G, Russell S, O'Donnell A, Kaner E, Trezona A, Rademakers J, Nutbeam D. What is the evidence on existing policies and linked activities and their effectiveness for improving health literacy at national, regional and organizational levels in the WHO European region. World Health Organization. Regional Office for Europe. 2018. https://apps.who.int/iris/handle/10665/326251

Beküldve: $\quad$ 2020. 01.13.

doi: $\quad$ 10.24365/ef.v61i1.555

Kulcsszavak: egészségműveltség; szakpolitika; egészségegyenlőtlenség; bizonyítékok összegzése

Keywords: health literacy; policy; heath inequality; evidence synthesis

\section{BEVEZETÉS}

Napjainkban egyre növekvő figyelemnek örvend az egészségmúveltség, mint az egészségfejlesztés eszköze. A szerzők bizonyítékok összegzése alapján mutatják be az egészségmúveltségre vonatkozó szakpolitikákat az Egészségügyi Világszervezet (World Health Organization, WHO) Európai Régiójában. A jelentés kiterjed az egészségmúveltség országos, regionális és szervezeti szintű megoszlásának, valamint az előzmények, szereplőik, a tevékenységek és eredmények, továbbá a hatékonyságot befolyásoló tényezők bemutatására.

\section{IS AZ EGÉSZSÉGMŰVELTSÉG?}

Az egészségmúveltség az egyének, a családok és a közösségek képessége arra, hogy az egészségüket érintő kérdésekben megalapozott döntéseket hozzanak a mindennapi élet területein, beleértve az egészségügyi ellátórendszert és a politika színterét is. 'Az egészségmúveltséggel kapcsolatos ismeretek bővítése elengedhetetlen stratégia ahhoz, hogy az egyének képessé váljanak egészségük jobb felügyeletére, egészséggel kapcsolatos információk felkutatására, egészségügyi kérdésekben való megnyilvánulásra, valamint felelősséget vállaljanak saját egészségi állapotukért. Az alacsony mértékű egészségmúveltség rosszabb egészségi állapottal, több egészségi problémával és nagyobb egészségegyenlőtlenségekkel, valamint kevésbé hatékony egészségügyi ellátórendszerrel jár együtt. Az egészségmúveltség fejlesztése az egyének egészséggel kapcsolatos képességeinek (capacities for health) növelésével javítja az egészséget, e mellett az egészségügyi ellátórendszer hatékonyságát, csökkenti az egészségegyenlőtlenségeket.

Az egészségmúveltség mértékére vonatkozó adatok sajnos nem állnak rendelkezésre a WHO Európai Régiójának minden tagállamában. A 2011-ben nyolc

¡További információk az egészségmúveltség fogalmáról: Csizmadia P. Az egészségmúveltség definíciói. Egészségfejlesztés, 2016. 3. szám; doi: 10.24365/ef.v57i3.68 
európai uniós országban lezajlott Európai Egészségmúveltség Felmérés (European Health Literacy Survey) eredményei szerint, a kutatásban résztvevők 47 százalékának problémás vagy elégtelen volt az egészségmúveltsége." Magyarország esetében ugyanezen felmérés eredménye 2015-ben azt mutatta, hogy a lakosság 52 százalékénak nem elegendő mértékű az egészségmúveltsége.iii

\section{MÓDSZER}

A bizonyítékokat szakbírálaton átesett (peerreviewed), valamint szürke irodalmi (grey literature) tanulmányokat gyújtő adatbázisok áttekintésével, valamint egy regionális - kizárólag az Európai Unió országaira vonatkozó - szakértői jelentésből (HEALIT4EU) nyerték a tanulmány szerzői. A bizonyítékok keresését 2017 októbere és 2018 januárja között angolul, németül és hollandul folytatták az alábbi szakbírált folyóirat-adatbázisokban: CINAHL (Cumulative Index to Nursing and Allied Health Literature), EMBASE, MEDLINE, PsycINFO és Web of Science. A szürke irodalmi adatbázisokban angol, német, francia, olasz, katalán, spanyol és orosz nyelven kerestek. A beválogatási kritériumoknak akkor felelt meg egy tanulmány, ha szerepelt benne az egészségmúveltség (health literacy) kifejezés, valamint magában foglalta a WHO egészségmúveltség szakpolitika definícióját.

A szakbírálaton átesett tanulmányok között a duplikátumok eltávolítása után 15.300 cikket találtak, melyből 12 cikk felelt meg a keresési feltételeknek. Ennek eredményeként 4 szakpolitikai intézkedéshez kapcsolódó tevékenységet, 4 szakpolitikát, valamint 3 olyan dokumentumot azonosítottak, amelyek a sikeres szakpolitikai implementáció végrehajtásának akadályait és facilitátorait ismertették. A szürke irodalomban további 15 szakpolitikai intézkedésre leltek, 26 intézkedést a szakértői vizsgálat során, míg másik 7 szakpolitikai intézkedést a HEALIT4EU tanulmányban találtak. Az újabb másodpéldányok kiszűrése után összesen 46 egészségmúveltséggel kapcsolatos szakpolitikát, valamint 3 szakpolitikai akadályt, facilitátort és hatékonyságot vizsgáló dokumentumot azonosítottak. Ezeket továbbították a WHO Európai Egészséginformáció Akciócsoport az Egészségmúveltség Mérésére Bizottságnak (WHO European Health Information Initiative Action Network on Measuring Health Literacy). E testület 19 olyan tagállam képviselőit vonta be a kiszúrt dokumentumok ellenőrzése és az esetlegesen hiányzó szakpolitikák azonosítása miatt, amelyekben találtak szakpolitikai intézkedéseket.iv

Elgondolkodtató, hogy a WHO Európai Régiójába tartozó Független Államok Közösségének országai vonatkozásában nem sikerült egészségmúveltség javítását célzó szakpolitikai intézkedéseket azonosítani.

\section{EREDMÉNYEK}

Ez a tanulmány 46 már meglévő és/vagy kialakítás alatt álló egészségműveltségre vonatkozó szakpolitikát azonosított a WHO Európai Régiójának 19 tagállamában. Ezek között nemzetközi (3 tagállam részvételével), országos, vagy helyi szintűek egyaránt voltak. A 46 szakpolitikai intézkedésből 43-ról volt részletes információja a jelentés íróinak, mivel 3 intézkedés még kidolgozás alatt állt. Szakpolitikai szakasz szerint 5 országos szintû szakpolitika kidolgozás alatt állt, 30 jelenleg is hatályban van (ebből 1 nemzetközi, 23 országos és 6 helyi szintű), 11 országos szintű intézkedés pedig időben korlátozott volt és folytatásukról nincs adat.

A szakpolitikákat az újonnan létrehozott egészségmúveltség szakpolitikai modell (health literacy policy model) alapján vizsgálták 4 társadalmi szint (egyéni, közösségi, szervezeti és rendszer) szerint, illetve 6 vektor (élethosszig tartó tanulás, lakókörnyezet, foglalkoztatás, média, digitális/e-egészség, egészségügyi szolgáltatások) mentén.

A 46 azonosításra került szakpolitikai intézkedés közül 28 (61\%) esetében tervezték az eredmények értékelését, 15 (33\%) beavatkozás semmilyen erre vonatkozó tervet nem tartalmazott és további 3 intézkedés kidolgozás alatt volt, így azok esetében az értékeléséről a tanulmány szerzőinek nem volt tudomása. A szakpolitikai intézkedések értékelését,

\footnotetext{
ii Ausztria, Bulgária, Görögország, Írország, Hollandia, Lengyelország, Németország (Észak-Rajna-Vesztfália) és Spanyolország

iii Koltai JA, Kun E. A magyarországi egészségértés nemzetközi összehasonlításban. Egészségfejlesztés, 2016. 3. szám; doi: 10.24365/ef.v57i3.62

${ }^{i v}$ A WHO Európai Egészséginformáció Akciócsoport az Egészségmúveltség Mérésére Bizottságba meghívott tagállamok az alábbiak voltak: Ausztria, Belgium, Csehország, Egyesült Királyság, Horvátország, Finnország, Franciaország, Izrael, Írország, Németország, Olaszország, Orosz Konföderáció, Portugália, Románia, San Marino, Spanyolország, Svájc, Svédország és Szlovénia.
} 
hatékonyságuk mérését számos esetben nem egy, hanem többféle módszerrel vizsgálták. Az értékelés leggyakoribb módja a céleredmények elérésének megerősítése volt, ami nem teszi lehetővé a hatékonyság mértékét, erre kvalitatív és kvantitatív módszereket használtak több tanulmányban is. $A$ jelentés szerzői minden értékelésen átesett szakpolitikai intézkedést az egészségműveltség szakpolitikai modelljén belül vizsgáltak. [1. ábra]

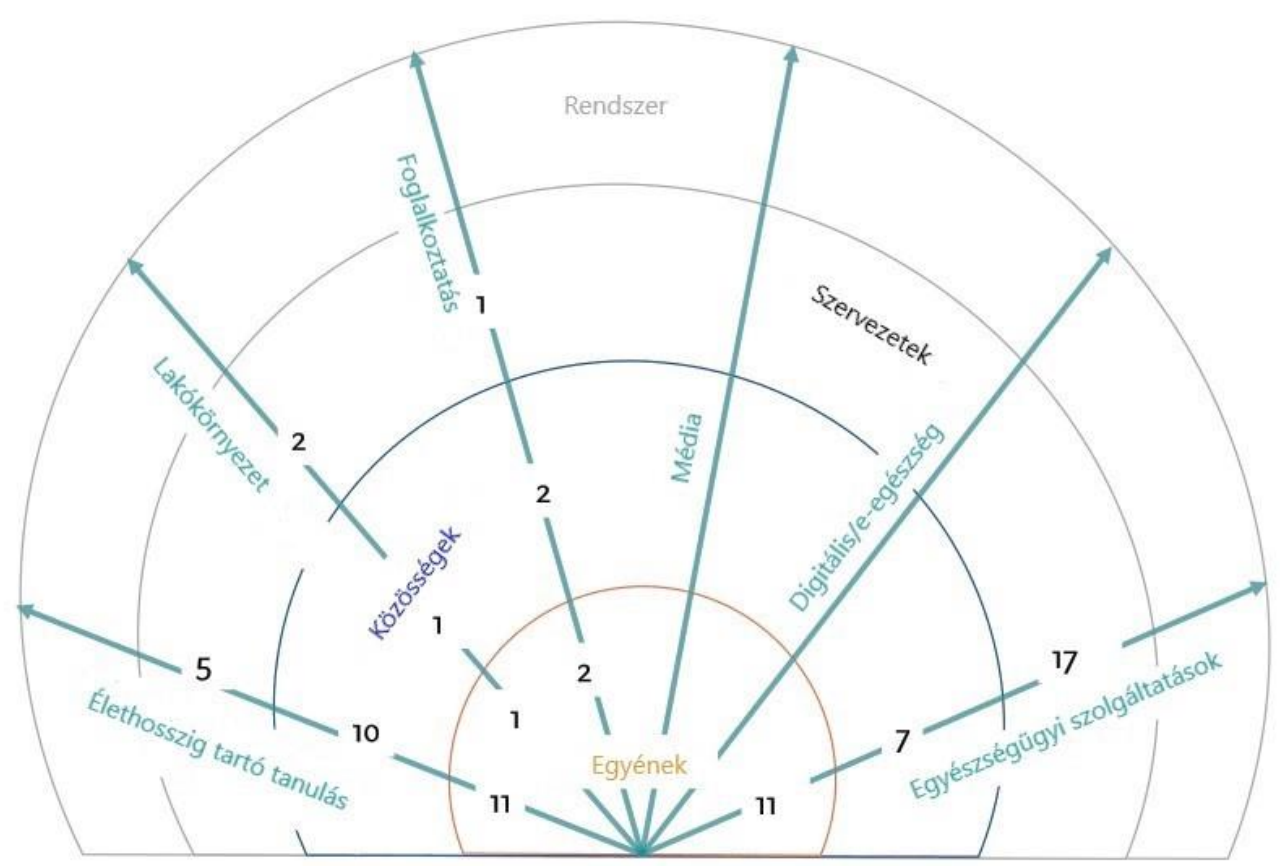

Forrás: az eredeti ábra magyar változata

A legtöbb értékelésen átesett szakpolitikai intézkedés az egészségügyi szolgáltatásokra és az élethoszszig tartó tanulás vektorain keresztül valósult meg egyéni, közösségi és szervezeti szinten. Néhány szakpolitikai intézkedés a lakókörnyezet, illetve a foglalkoztatás vektorára irányult. Az értékelt intézkedések közül egy sem valósult meg rendszerszinten, illetve célozta meg a média, digitális/ e-egészség dimenzióit.

Az egyéni szinten megvalósuló értékeléssel bíró szakpolitikai intézkedések többsége a krónikus betegek egészségműveltségének javítását célozta meg, ilyen például az osztrák "Szívügy” (Herzensbuildung) projekt, mely szívbetegeknek szólt és a betegséggel kapcsolatos egészségmúveltség növelésén kívül eredményesen csökkentette a dohányzók számát is. A finn oktatási rendszerben a 9-16 éves korú diákok egészségismereteket tanulnak, amelyek - felmérésekkel bizonyítottan - mélyítették a tanulók egészségmúveltségét.

A közösségi szintű szakpolitikai intézkedések főként hátrányos helyzetű csoportok egészségműveltségének javítását tűzték ki célul, ilyen például a Svédországba érkezett menekült nők kulturálisan adaptált egészségnevelése, mely magában foglalja a reprodukciós egészséggel kapcsolatos ismeretek átadását is, így növelve funkcionális, kritikai és interaktív egészségmúveltségük javítását. Az eredetileg Németországból indult, majd Ausztriára és Svájcra is kiterjesztett „Bevándorlókkal a bevándorlókért” (The MiMi project - With Migrants for Migrants) projekt az egészségügyi ellátás során jelentkező egészségegyenlőtlenségeket kívánja csökkenteni, valamint egészséggel kapcsolatos, kulturálisan adaptált információkat átadni, így növelve a bevándorlók egészségmúveltségét. 
A közösségi együttmúködésre további jó példa az Egyesült Királyságbeli Preston városa, ahol az egyes utcák feletti közösségi ellenőrzés a lakosságban jobban tudatosította a séta és a társas érintkezés okozta egészségnyereséget.

A szervezeti szintű szakpolitikai intézkedések olyan szakembereket céloztak meg, akik munkájuk során alacsony egészségmúveltségű kliensekkel találkoznak. A szakemberek olyan technikákat (mint például a visszatanítás, vagyis teach-back módszere) tanulhattak meg, melyekkel hatékonyan növelhetik klienseik egészségmúveltségét.

A jelentés összeállítása során a szerzők sajnos nem tudtak azonosítani olyan rendszerszintú szakpolitikai intézkedést, melynek hatékonyságát értékelték volna.

A jelentés készítői tehát bizonyítékokat találtak az egészségműveltség sikeres fejlesztésére egyéni és közösségi szinten - különösen az egészségügyi és oktatási ágazatban -, valamint néhány munkahelyi, mint színtéralapú intézkedésben. Több intézkedés célozta az egyéni készségek fejlesztését, mint a közösségiekét. Számos szakpolitikai intézkedésnek kiegészítő területei is vannak, ahol az ismeretek és az erőforrások megosztása hasznos lehet. Jelenleg kevés bizonyíték van a lakókörnyezet, a média és a digitális/e-egészségműveltség területén azok befolyásoló tevékenységekről és hasznáról, bár ezen információk egy részét talán megismerhetjük a jelenleg is folyó projektek értékelésekor. Az, hogy a szakbírálaton átesett adatbázisokban történő kereséskor kevés szakpolitikai intézkedést találtak a szerzők, talán annak is betudható, hogy az akadémiai közeg kevésbé érdeklődik a szakpolitikák értékelése iránt.

A politikai döntéshozókban tudatosítani kell, hogy az egészségmúveltséggel kapcsolatos szakpolitikák sikeres bevezetését facilitálhatja az ágazatközi együttmúködés, a támogató intézményi struktúrák és feladatok, a közösségi részvétel, a hálózati együttmúködés, a politikai vezetés és a kulturális akadályok legyőzése, valamint biztosítani kell, hogy gondosan mérlegeljék az olyan, bevezetést gátló bizonyítékok hiányát, mint a szakpolitikák egészségügyi, szociális és gazdasági hatása. Az egészségműveltséggel kapcsolatos szakpolitikák gazdasági hatásának vizsgálata fontos fejlődési terület, az ismertetett jelentés azonban nem talált semmilyen értékelést az adott szakpolitikák gazdasági hatását illetően.

\section{SZAKPOLITIKAI JAVASLATOK}

A fenti bizonyítékok összefoglalásaként a jelentés az alábbi, szakpolitikai javaslatokat teszi:

- Az egészségmúveltség fejlesztését vagy javítását célzó szakpolitikák és intézkedések kidolgozásakor vegyék figyelembe a jelentésben bemutatott szakpolitikákat és a hozzájuk kapcsolódó tevékenységeket, hogy azok az állampolgárok, betegek és közösségek javát szolgálják.

- Bővítsék úgy a holisztikus egészségműveltséggel kapcsolatos szakpolitikai tevékenységek területét, hogy azok magukba foglalják a lakókörnyezetet, munkahelyet, a médiát és a digitális/e-egészséget minden társadalmi szinten (egyéni, közösségi, szervezeti és jogalkotói rendszer).

- Az egészségmúveltséget célzó intézkedéseket bizonyítékokra alapozzák minden társadalmi területen annak érdekében, hogy a szakpolitikák megfeleljenek az országos vagy helyi szükségleteknek.

- Az egészségügyi szakpolitikák és beavatkozások értékelése minőségileg és mennyiségileg történjen; a kvantitatív értékelési módszerek magukba foglalhatják a tevékenység előtti és utáni egészségműveltségi szint mérését, valamint az egészségügyi, szociális és gazdasági hatások értékelését minden szinten.

Az egészségmúveltséget célzó szakpolitikák végrehajtási folyamatába beépíthetik a kulturális akadályok csökkentése érdekében a szükséges ágazatközi együttműködést, politikai vezetést és stratégiákat. 


\section{TANULSÁGOK A HAZAI SZAKEMBEREK SZÁMÁRA}

$\mathrm{Az}$ ismertetett jelentésben leírt keretrendszer alkalmazásával és a szakpolitikák hatékonyságának mérésével a döntéshozóknak lehetősége lenne Magyarországon is a lakosság egészségmúveltségének fejlesztésére és a társadalomban jelenlévő egészségegyenlőtlenségek csökkentésére. Mivel egy 2015-ben végzett felmérés szerint a magyarok mintegy felének nem megfelelő az egészségmúveltsége, szükség lenne hatékony szakpolitikai intézkedésekre, melyek remélhetőleg javulást eredményeznének a lakosság egészségi állapotában, valamint az egészségügyi ellátórendszer túlterheltségében.

\section{TÁMOGATÁS}

A publikáció elkészítését a GINOP-2.3.2-15-2016-00005 számú projekt támogatta. A projekt az Európai Unió támogatásával, az Európai Regionális Fejlesztési Alap társfinanszírozásával valósult meg. 